\title{
WOJCIECH SIECZKOWSKI
}

\section{Behawioralne aspekty decyzji dotyczących dodatkowego zabezpieczenia emerytalnego [wnioski dla Polski)}

Celem artykułu jest przedstawienie pojęcia racjonalności oraz wskazanie ograniczeń racjonalności udokumentowanych w ekonomii behawioralnej jako podstaw do tworzenia metod behawioralnych majacych na celu poprawę jakości decyzji dotyczacych dodatkowego zabezpieczenia emerytalnego. Na podstawie dogłębnej analizy literatury przedmiotu przedstawiono postulat o potrzebie dostosowania wybranych rozwiqzań behawioralnych do specyficznych warunków systemu emerytalnego w Polsce.

Słowa kluczowe: racjonalność wyborów, zabezpieczenie emerytalne, ekonomia behawioralna, decyzje emerytalne, metody behawioralne.

\section{Wprowadzenie}

System emerytalny można przedstawić jako narzędzie alokacji aktywów w cyklu życia ${ }^{1}$. Kierunek reformowania systemów zabezpieczenia emerytalnego powoduje, że znacząco wzrasta rola dozabezpieczenia (doubezpieczenia) emerytalnego ${ }^{2}$. Pozostawienie dobrowolności w jakiejkolwiek formie i którejkolwiek części systemu zabezpieczenia emerytalnego łączy się - przynajmniej w pewnym stopniu - z przeniesieniem odpowiedzialności za poziom zabezpieczenia emerytalnego na indywidualnych uczestników systemu. Tego rodzaju zmiany wymagaja przede wszystkim inicjatywy przyszłego beneficjenta w zakresie przystapienia do konkretnego programu (planu), podejmowania trafnych decyzji oszczędnościowych (inwestycyjnych) i wyboru formy wypłat środków emerytalnych. Rodzą się wówczas wạtpliwości dotyczące mechanizmów i jakości podejmowanych wyborów, a zwłaszcza pytanie: czy postępowanie uczestników jest w pełni racjonalne?

1. M. Góra, System emerytalny, Wydawnictwo Ekonomiczne, Warszawa 2003, s. 48.

2. T. Szumlicz, Ubezpieczenie społeczne. Teoria dla praktyki, Oficyna Wydawnicza Branta, Bydgoszcz-Warszawa 2005 , s. 243. 
W literaturze przedmiotu, coraz częściej dostrzega się znaczenie i ważność analizy czynników behawioralnych ${ }^{3}$. Wydaje się, że następuje zmiana paradygmatu i do głosu dochodzi założenie, iż konstrukcja wyboru ma istotny wpływ na podejmowane decyzje ${ }^{4}$. W tym kontekście istotne jest przede wszystkim dokładne przedstawienie pojęcia racjonalności używanego w ekonomii behawioralnej ${ }^{5}$, a następnie rozróżnienie pomiędzy częścią eksplanacyjną (wyjaśnieniem procesów poznawczych, czynników, mechanizmów) oraz częścią preskryptywną (technikami, metodami, narzędziami, interwencjami] ekonomii behawioralnej ${ }^{6}$.

Celem artykułu jest przedstawienie pojęcia racjonalności oraz wskazanie ograniczeń racjonalności opisanych w ekonomii behawioralnej jako podstaw do tworzenia metod behawioralnych mających na celu poprawę jakości decyzji dotyczących dodatkowego zabezpieczenia emerytalnego.

Na podstawie przeprowadzonego wywodu syntetycznie przedstawiony zostanie katalog metod behawioralnych i postulat potrzeby dostosowania rozwiązań znanych z doświadczeń innych państw do specyfiki polskiego systemu zabezpieczenia emerytalnego?

\section{Zagadnienie racjonalności a ewolucja nurtu behawioralnego w ekonomii}

Ekonomia behawioralna nie jest jednolitą szkoła. W historii tego nurtu widoczna jest istotna ewolucja pogladów i wpływ innych nauk społecznych. Esther-Mirjam Sent ${ }^{8}$ proponuje wyróżnienie

3. S. Pieńkowska-Kamieniecka, Wybrane aspekty dodatkowego oszczędzania emerytalnego - perspektywa behawioralna, „Studia Oeconomica Posnaniensia” 2017, vol. 5, no. 10, s. 9-22.

4. W. Sieczkowski, Decyzje oszczędnościowe w systemie zabezpieczenia emerytalnego, [w:] Doubezpieczenie społeczne - idea i kontynuacja, [red.] M. Kawiński, Szkoła Główna Handlowa, Warszawa 2015, s. 100.

5. Ekonomia behawioralna nie zakłada, że człowiek jest nieracjonalny.

6. R. Münschner, M. Vetter, T. Scheuerle, A Review and Taxonomy of Choice Architecture Techniques, „Journal of Behavioral Decision Making" 2015, s. 1.

7. Autor proponuje wyraźne rozróżnienie pojęć związanych z ekonomią behawioralna, przedstawione w zestawieniu poniżej.

\begin{tabular}{|l|l|l|}
\hline \multicolumn{1}{|c|}{ Część eksplanacyjna } & \multicolumn{1}{|c|}{ Część preskryptywna } & \multicolumn{1}{c|}{ Zastosowania } \\
\hline $\begin{array}{l}\text { procesy poznawcze, inklinacje, } \\
\text { czynniki, mechanizmy }\end{array}$ & $\begin{array}{l}\text { techniki, metody, narzędzia, } \\
\text { interwencje, rozwiązania }\end{array}$ & $\begin{array}{l}\text { doświadczenia pochodzace z reform } \\
\text { przeprowadzonych na świecie }\end{array}$ \\
\hline
\end{tabular}

Pierwsze kryterium to procesy poznawcze, czyli ograniczenia psychiczne i ewentualne błędy, które są przedmiotem interwencji. Drugie to metody behawioralne pogrupowane zgodnie z rodzajem interwencji. Ostatnie to studia przypadków dokumentujących wdrożenie w poszczególnych państwach.

W niniejszym artykule dogłębnej analizie została poddana część eksplanacyjna, natomiast syntetycznie zaprezentowano metody (interwencje) behawioralne rekomendowane do ewentualnego zaadaptowania w Polsce. Zastosowania są przedmiotem innych opracowań, cel niniejszej pracy nie wymaga ich powielania - por. OECD (2014), OECD Pensions Outlook 2014, OECD Publishing, s. 149-174. W. Sieczkowski, Reforma systemu emerytalnego w Wielkiej Brytanii, „Wiadomości Ubezpieczeniowe” 2014, nr 2; M. Szczepański, Wykorzystanie dorobku ekonomii behawioralnej w reformowaniu systemów emerytalnych, „Polityka Społeczna” 2017, nr 8; S. Pieńkowska-Kamieniecka, Wybrane aspekty ..., s. 9-22 i W. Sieczkowski, Decyzje oszczędnościowe ..., op. cit.

8. Esther-Mirjam Sent przedstawia historię rozwoju ekonomii behawioralnej w E.-M. Sent, Behavioral Economics: How Psychology Made Its (Limited) Way Back Into Economics, „History of Political Economy” 2004, 36 (4), s. 735-760. W literaturze polskiej zwięzłe opracowania stanowią: A. Solek, Ekonomia behawioralna a ekonomia neoklasyczna, „Zeszyty Naukowe - Polskie Towarzystwo Ekonomiczne” 2010, nr 8 i J. Godłów-Legiędź, Ekonomia behawioralna: od koncepcji racjonalności do wizji ustroju ekonomicznego, „Ekonomia” 2013, nr 4(25). 
„Starej” i „nowej” szkoły. Pierwszy okres to lata 50. i 60. XX wieku, natomiast lata 90. to okres „nowej” szkoły, ukształtowanej po okresie przejściowym w latach 70. i 80. Ewolucja dokonała się od odrzucenia teorii neoklasycznej do jej uzupełnienia. Zmniejszający się krytycyzm neoklasycznych założeń i metod charakteryzował przejście od pierwszego do drugiego okresu i jest kluczowy dla zrozumienia ewolucji pojęcia racjonalności w ekonomii behawioralnej.

Centralnym punktem „starej” ekonomii behawioralnej jest definicja racjonalności i przekonanie, że ekonomia nie powinna naśladować nauk przyrodniczych. Złożoność zjawisk ekonomicznych prowadziła do odrzucenia idei homo oeconomicus na rzecz ograniczonej racjonalności oraz użycia zwyczajów i abstrakcyjnych, nieformalnych, nieopisanych reguł, których źródeł nikt nie zna. Pojawiło się nawiązanie do dwóch form racjonalności - konstruktywistycznej i ekologicznej - w odniesieniu do dwóch form indywidualizmu. Racjonalność konstruktywistyczna pochodzi od standardowego modelu nauki Descartes'a, który zakłada że jedynie świadomy proces myślenia powinien decydować o kierunku rozwoju społeczeństwa i jego instytucji. Racjonalność ekologiczna lub racjonalny porządek społeczny wynikają z tego, że ludzie działają zgodnie z regułami, których moga nie potrafić wyartykułować, niemniej które są odkrywalne ${ }^{9}$.

Korzenie „nowej” szkoły ekonomii behawioralnej to lata ?0. XX wieku ${ }^{10}$. W tym wypadku również trudno o jednolitość. Interesującą analogia posługuje się John F. Tomer, który do opisania nurtów szkoły behawioralnej używa obrazu nitek tworzących linę ${ }^{11}$. Na samym wstępie należy wyjaśnić, że w „nowej” ekonomii behawioralnej nie odnajdziemy twierdzenia, jakoby człowiek był irracjonalny. W nurcie tym

9. Historię początków „starej” szkoły, zwłaszcza jej związków z myślą Friedricha Hayeka, przestawiają R. Frantz i R. Leeson w: Hayek and Behavioural Economics, Palgrave-Macmillan UK, London 2013. Szerzej na temat myśli Hayeka zob. np. P. Leszek, Interpretacja własności w doktrynie Hayeka: ewolucyjny przypadek usankcjonowany korzyściq, „Wrocławskie Studia Erazmiańskie” 2009, zeszyt III http://www.bibliotekacyfrowa.pl/ Content/34392/0007.pdf [dostęp: 24.01.2018].

10. E.-M. Sent, op. cit., s. 742.

11. J.F. Tomer, What is behavioural economics? „The Journal of Socio-Economics” 2007, no. 36, s. 463-479; przedstawia następujące nurty:

- Herbert Simon (noblista - 1978) i szkoła Carnegie: podważali podstawowe założenia racjonalności i egoizmu.

- George Katona i szkoła Michigan: rozwinęli ekonomię behawioralną, która podkreślała znaczenie psychologii.

- Psychologia ekonomiczna: odłam ten znacząco czerpie z psychologii poznawczej, w celu urzeczywistnienia zrozumienia myśli ekonomicznej. Przedstawicielami są Colin Camerer, Ernst Fehr, Daniel Kahnemann (noblista - 2002), David Laibson, George Loewenstein, Matthew Rabin i Richard Thaler (noblista - 2017).

- Teoria efektywności „X” Harveya Leibensteina. Przedstawicielami tej szkoły są Shlomo Maital, Morris Altman, Roger Frantz, John Tomer. Kwestionowali twierdzenie, że ludzie maksymalizują własną użyteczność. Postulat egoizmu nie był przez nich podważany. W tej teorii agent jest istota społeczna, ograniczoną zobowiązaniami społecznymi, normami i konwencjami, identyfikacją i postawą współpracy.

- Makroekonomia behawioralna: George Akerlof (noblista - 2001). Szkoła wywodząca się z koncepcji Keynesa, ale z solidnym gruntem psychologii i socjologii.

- Teoria ewolucyjna: Nelson Winter, zapożyczenia z biologii, zwłaszcza teorii Darwina o selekcji naturalnej.

- Finanse behawioralne Jest to stosowana odnoga ekonomii behawioralnej. Ma bardzo silne związki zwłaszcza z psychologia ekonomiczną. Przedstawicielami są Richard Thaler (noblista - 2017), Robert Shiller (noblista - 2013), Andrew Shleifer, Hersh Shefrin.

- Ekonomia eksperymentalna: Vernon Smith (noblista - 2002) - zasadniczo jest to metodologicznie technika, a nie oddzielny nurt badawczy. Pomimo iż wyniki badań wskazują, że decydenci nie są tak racjonalni, jak przewiduje teoria neoklasyczna, to jednak rynki okazują się bardziej wydajne, aniżeli można by się spodziewać przez wgląd na brak racjonalności. 
nie ma dążenia do zastapienia założeń standardowej teorii nowymi ${ }^{12}$. „Nowa” ekonomia behawioralna polega na połączeniu lub uzupełnieniu szkoły neoklasycznej. Powstał nowy model opisania ograniczeń racjonalności, w którym punktem wyjścia jest standard neoklasyczny - nie zaś odrzucenie założeń tego modelu ${ }^{13}$. Richard Thaler ${ }^{14}$ stwierdza na przykład, że wyższość deskryptywna teorii perspektywy nie oznacza, że teorię użyteczności należy odrzucić. Nie ma lepszego narzędzia niż neoklasyczna teoria oczekiwanej użyteczności, aby nauczyć ludzi, jak należy postępować ekonomicznie poprawnie. Nurt behawioralny jedynie pomaga wskazać, jak ludzie zachowują się tak naprawdę.

Modele neoklasyczne używaja uproszczenia ludzkiego zachowania, redukując je do działania mędrca, pozbawionego emocji, posiadającego wszystkie istotne informacje i będącego w stanie prawidłowo uwzględniać wszystkie zmienne, oszacować prawdopodobieństwo ich wystapienia i odpowiednio ocenić ich wagi ${ }^{15}$. Ekonomia behawioralna zwiększa wydajność przewidywania modeli ekonomicznych przez dostarczenie bardziej realistycznych fundamentów psychologicznych. Nie odrzuca modeli neoklasycznych, a tylko zmienia ich założenia. Założenia te dotyczą zwłaszcza ograniczeń zdolności i mocy obliczeniowej przeciętnego człowieka, siły woli oraz egoizmu ${ }^{16}$.

W tym miejscu warto zauważyć, że w krytykę ograniczeń ekonomii behawioralnej wkład maja zarówno ekonomiści, jak i psychologowie ${ }^{17}{ }^{18}$. Zarzuty dotyczą tego, że ekonomia behawioralna to wypadkowa dwóch rewolucji. Po pierwsze, istotną rolę odegrała rewolucja marginalna oraz wyłączenie instytucjonalizmu poza wiodący nurt ekonomii. Dominacja modeli racjonalności z wnioskowaniem statystycznym oraz maksymalizacją użyteczności oznacza, że w porównaniu z nimi wszelkie odstępstwa są traktowane jako porażka umysłu ludzkiego, błąd polegający na braku zastosowania racjonalnych zasad myślenia i wnioskowania ${ }^{19}$. Po drugie, w połowie XX wieku popularne w psychologii stało się odejście od behawiorystycznego postrzegania człowieka (automatyzm: bodziec-reakcja] na rzecz rozwoju teorii poznawczych, opartych o wizje człowieka jako jednostki przetwarzającej informacje. Rozwojowi ekonomii behawioralnej towarzyszyło więc, paradoksalnie, odejście od behawioryzmu w psychologii ${ }^{20}$. Lata 70. XX wieku to rozwój psychologii poznawczej, a także teorii różnic indywidualnych, czerpiących z metod psychometrycznych.

W „nowej” ekonomii behawioralnej zauważa się, że stosowanie różnych heurystyk (skrótów) jest bardzo pomocne i bardzo często skuteczne. Niemniej jednak niekiedy zawodzi oraz w sposób

12. Zob. np. R.H. Thaler, H.M. Shefrin, An Economic Theory of Self-Control, „Journal of Political Economy” 1981, 89, 2 April, s. 392-406 oraz wiele innych.

13. E.-M. Sent, op. cit, s. 743.

14. R.H. Thaler, Quasi Rational Economics, Russell Sage Foundation, New York 2000, s. 119.

15. O.S. Mitchell, S.P. Utkus, Pension design and structure: new lessons from behavioral finance, Oxford University Press, 0xford 2004, s. 3.

16. C.F. Camerer, G. Loewenstein, Behavioral economics Past, Present, Future, Princeton University Press, Princeton-0xford,2004, s. 3-4.

17. J. Godłów-Legiędź, op. cit.

18. D.G. Goldstein, G. Gigerenzer, Models of ecological rationality: The recognition heuristic, „Psychological Review” 2002, vol. 109, no. 1, s. 75.

19. K. Fiedler, M. von Sydow, Heuristics and Biases: Beyond Tversky and Kahneman's (1974) Judgment under Uncertainty, [w:] M.W. Eysenck, D. Groome, Cognitive Psychology: Revisiting the Classical Studies, Sage, Los Angeles-London 2015, s. 146.

20. J. Godłów-Legiędź, op. cit., s. 2 ?. 
przewidywalny odbiega od założeń racjonalności. Do opisu takiego regularnego, ale nieracjonalnego postępowania proponowane jest określenie „quasi-racjonalny”21.

Można zatem stwierdzić, iż behawioralne podejście zakłada bardziej realistycznie, że każdy podmiot ekonomiczny musi podejmować decyzje bez dostępu do pełnej informacji, ma ograniczone zdolności poznawcze i jest podatny na błędy w myśleniu i działaniu, aczkolwiek jego działanie jest regularne i przewidywalne, choć niedoskonale racjonalne.

\section{Główne ograniczenia racjonalności udokumentowane teoretycznie w ekonomii behawioralnej}

Neoklasyczna teoria podejmowania decyzji jest oparta na koncepcji oczekiwanej użyteczności. Jest to teoria normatywna, która wskazuje działania służące maksymalizacji funkcji użyteczności, lecz nie opisuje zachowań w danych sytuacjach ${ }^{22}$. Vilfredo Pareto, zamiast szukać obiektywnych mierników użyteczności, utożsamiał subiektywne preferencje z dokonywanymi wyborami²3. Teoria użyteczności zdominowała nauki ekonomiczne ze względu na prawdziwie racjonalne zachowanie w warunkach niepewności.

W odróżnieniu od modelu neoklasycznego model behawioralny zakłada, że ludzie dla wygody lub z powodu ograniczeń poznawczych korzystają ze skrótów myślowych. Jednostki podejmuja decyzje w oparciu o niepełną informację i ograniczoną zdolność ich przetwarzania. Dlatego też ludzie nie dążą do maksymalizacji swojej użyteczności, a wystarczy im zwykle uzyskanie satysfakcjonującego poziomu użyteczności² .

W opisie intuicyjnej oceny prawdopodobieństwa w warunkach niepewności Daniel Kahneman i Amos Tversky ${ }^{25}$ odwołują się do heurystyk. Punktem wyjścia dla tych badaczy była teoria neoklasyczna, której wybrane założenia zostały zanegowane. ${ }^{26}$ Autorzy podważyli aksjomaty przechodniości i zauważyli odchylenia od racjonalności zakładanej w teorii neoklasycznej.

\subsection{Heurystyki poznawcze}

Kahneman i Tversky używają trzech heurystyk ${ }^{27}$ : reprezentatywności, dostępności i zakotwiczenia. Heurystyki to uproszczenia w oszacowaniu bardziej złożonych problemów, metody podejmowania decyzji w warunkach niepewności i ryzyka ${ }^{28}$.

21. R.H. Thaler, op. cit., s. 241.

22. A. Solek, Ekonomia behawioralna ..., s. 22.

23. Ibidem, s. 1.

24. Ibidem, s. 24.

25. To właśnie tych autorów wskazuje się jako prekursorów ekonomii behawioralnej, jednakże w świetle przedstawionego wcześniej zarysu ewolucji tej dyscypliny moga być oni uznani jedynie za prekursorów odrodzenia „nowej szkoły”.

26. D. Kahneman, A. Tversky, Prospect Theory: An Analysis of Decision under Risk, „Econometrica” 1979, 47 (2), March, s. 263-291.

27. D. Kahneman, A. Tversky, Judgment under uncertainty: Heuristics and biases, „Science” 1974, vol. 185, no. 4157.

28. P. Bańbuła, Oszczędności i wybór międzyokresowy - podejście behawioralne, „Materiały i Studia” Narodowy Bank Polski 2006, z. 208. s. 19. 
Tabela 1. Podstawowe heurystyki poznawcze

\begin{tabular}{|c|c|c|c|}
\hline $\begin{array}{l}\text { Heury- } \\
\text { styka }\end{array}$ & $\begin{array}{c}\text { Pole } \\
\text { zastosowania }\end{array}$ & Opis & Przykłady \\
\hline 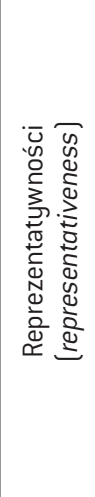 & $\begin{array}{l}\text { Oceny praw- } \\
\text { dopodobień- } \\
\text { stwa } \\
\text { przynależ- } \\
\text { ności } \\
\text { przypadków } \\
\text { do jakiejś } \\
\text { kategorii }\end{array}$ & $\begin{array}{l}\text { Heurystyka ta pozwala na dostrzega- } \\
\text { nie trendów w losowych sekwencjach } \\
\text { zdarzeń. Prowadzi ona do następu- } \\
\text { jących błędów: } \\
\text { 1) niewrażliwość na wyjściowe praw- } \\
\text { dopodobieństwo uzyskania wy- } \\
\text { ników, } \\
\text { 2) niewrażliwość na wielkość próby, } \\
\text { 3) błędne rozumienie szansy, } \\
\text { 4) niewrażliwość na realne możliwo- } \\
\text { ści prognostyczne, } \\
\text { 5) iluzja poprawności, } \\
\text { 6] błędne rozumienie zjawiska re- } \\
\text { gresji. }\end{array}$ & $\begin{array}{l}\text { Ludzie wyciagają wnioski z przeszłych wy- } \\
\text { darzeń w celu oszacowania prawdopodo- } \\
\text { bieństwa wystapienia zdarzeń podobnych. } \\
\text { Naiwna ekstrapolacja pozwala np. traktować } \\
\text { przeszłe wyniki funduszy inwestycyjnych jako } \\
\text { predykator przyszłych zysków. Ludzie zawy- } \\
\text { żaja niskie prawdopodobieństwa i zaniżaja } \\
\text { umiarkowane i wysokie prawdopodobieństwa. }\end{array}$ \\
\hline  & $\begin{array}{l}\text { Pamięciowe } \\
\text { oceny } \\
\text { częstości lub } \\
\text { prawdopodo- } \\
\text { bieństwa }\end{array}$ & $\begin{array}{l}\text { Jest uproszczona metoda oceny } \\
\text { prawdopodobieństwa, narażoną } \\
\text { na następujące błędy: } \\
\text { 1) obciążenia wynikające z łatwości } \\
\text { przypomnienia; } \\
\text { 2) obciążenia wynikające z efektyw- } \\
\text { ności wyszukiwania; } \\
\text { 3) obciążenia wynikające z moż- } \\
\text { liwości wyobraźni.Pamięciowe } \\
\text { oceny częstości lub prawdopo- } \\
\text { dobieństwa }\end{array}$ & $\begin{array}{l}\text { Przeszacowanie ryzyka, które można łatwo so- } \\
\text { bie przypomnieć. Ludzie przeszacowują praw- } \\
\text { dopodobieństwo, jeżeli informacja dotycząca } \\
\text { podobnego wydarzenia jest łatwo dostępna. } \\
\text { Na przykład wybór produktu oszczędnościo- } \\
\text { wego lub funduszu inwestycyjnego może być } \\
\text { oparty o niepełną lub błędną informację, która } \\
\text { jest dostępna przypadkowo. }\end{array}$ \\
\hline 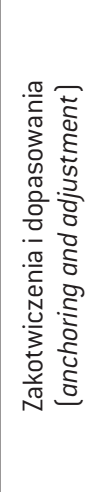 & $\begin{array}{l}\text { llościowe } \\
\text { oszacowania } \\
\text { na jakiejś } \\
\text { skali }\end{array}$ & $\begin{array}{l}\text { Obliczenia kosztu są zniekształcane } \\
\text { przez wartość początkową. } \\
\text { Błędy wynikające z niej to: } \\
\text { 1) niewystarczajace dopasowanie; } \\
\text { 2) obciążenia w szacowaniu łącz- } \\
\text { nych i rozłącznych zdarzeń.lloś- } \\
\text { ciowe oszacowania na jakiejś skali }\end{array}$ & $\begin{array}{l}\text { Zakotwiczenie dotyczy tego, że różne alter- } \\
\text { natywy nie sa postrzegane jako jedna całość } \\
\text { (np. ocena zmiany odnośnie całego boga- } \\
\text { ctwa), tylko jako zyski lub straty odnośnie } \\
\text { jakiegoś mentalnego benchmarku lub punktu } \\
\text { odniesienia opartego o własne doświadczenia } \\
\text { (efekt kadrowania / oprawy). } \\
\text { Heurystyka zakotwiczenia wpływa na zacho- } \\
\text { wania inwestycyjne i decyzje oszczędnościo- } \\
\text { we przynajmniej w trzech aspektach: } \\
\text { - w sposobie inwestowania (wybór aktywów), } \\
\text { - w wielkości i rozmiarze inwestycji, } \\
\text { - w oszacowaniu oczekiwanej sytuacji eme- } \\
\text { rytalnej w odniesieniu do sytuacji rodziców. }\end{array}$ \\
\hline
\end{tabular}

Źródło ${ }^{29}$ : opracowanie własne na podstawie: K. Fiedler, M. von Sydow, Heuristics and Biases: Beyond Tversky and Kahneman's (1974] Judgment under Uncertainty, [w:] M.W. Eysenck, D. Groome, Cognitive Psychology: Revisiting the Classical Studies, Sage, Los Angeles-London 2015, s. 147 i N. Brunhart, Individual Financial Planning for Retirement: Empirical Insights from the Affluent Segment in Germany: Contributions to Economics, PsychicaVerlag (Springer), Heidelberg, 2008.

29. K. Fiedler, M. von Sydow, op. cit., s. 146-161. 
Należy zauważyć, że takie rozumienie heurystyk i „wypaczeń” jest postrzegane jako „błędne” jedynie w odniesieniu do racjonalności konstruktywistycznej ${ }^{30}$. Takie spojrzenie spotyka się z krytyką w literaturze przedmiotu. Na przykład Daniel Goldstein i Gerd Gigerenzer uważają, że heurystyki są racjonalne, albowiem pozwalają na podejmowanie decyzji na podstawie ograniczonych informacji ${ }^{31}$. Wysiłek uwagi jest najważniejszym przejawem woli32 ${ }^{32}$ Ludziom biednym lub postrzegającym siebie jako biednych, trudniej jest oszczędzać. Wynika to z ograniczeń zasobu, jakim jest siła woli33. Uwzględniając ograniczenie tego zasobu, należy uznać, iż heurystyki stanowią w istocie bardzo ekonomiczne rozwiązanie dla skomplikowanych czynności ${ }^{34}$.

Tabela 1. zawiera prezentację podstawowych heurystyk poznawczych wraz z opisem i przykładami.

\subsection{Teoria perspektywy}

Teoria perspektywy jest złożona z dwóch części. Pierwsza z nich dotyczy odniesienia do stanu posiadania, jako punktu referencyjnego. Pierwsza część omawia, jak postrzegane są zyski i straty. Teoria perspektywy jest teoria podejmowania decyzji w warunkach niepewności, która podkreśla istotność sytuacji wyjściowej (status quo) oraz punkty odniesienia dotyczące preferencji i wyborów. Najważniejszym wnioskiem teorii perspektywy jest to, że ludzie inaczej postrzegaja i wartościuja zyski aniżeli straty.

Główna implikacja pierwszej części teorii perspektywy z punktu widzenia zabezpieczenia emerytalnego jest taka, że decydent przedkłada mniejszy, lecz pewny zysk nad podjęcie ryzyka, pomimo takiej samej wartości oczekiwanej ${ }^{35}$. Z drugiej strony, fakt że funkcja jest bardziej stroma w zakresie strat, oznacza silniejsze odczuwanie strat, niż zysków.

Rysunek 1. przedstawia wykres pierwszej części teorii perspektywy.

Druga część teorii perspektywy dotyczy subiektywnych wag przypisywanych prawdopodobieństwu. Bardzo nieprawdopodobne zdarzenia sa przeceniane. Natomiast zdarzenia bardzo prawdopodobne są niedoceniane ${ }^{36}$. Piotr Zielonka podkreśla, że funkcja wag decyzyjnych to ilustracja oceny prawdopodobieństw, którym przypisywane są subiektywne wagi, transformujące wartości prawdopodobieństwa w trakcie procesu podejmowania decyzji w warunkach ryzyka ${ }^{37}$,

30. „Nurt ten sprowadza wszelki, dający się odkryć, porządek społeczny do świadomego projektu człowieka, a jego zwolennicy - wychodząc z przeświadczenia, iz umysł ludzki posiada wiedzę i zdolności rozumowania niezależne od doświadczenia - dostrzegają we wszelkich osiągnięciach człowieka dzieło ludzkiego umysłu". Za: P. Leszek, op. cit., s. 98.

31. D.G. Goldstein, G. Gigerenzer, Models of ecological rationality: The recognition heuristic, „Psychological Review” 2002, vol. 109, no. 1, s. 75.

32. H.M. Shefrin, R.H. Thaler, The Behavioral Life-Cycle Hypothesis, [w:] R.H. Thaler, Quasi-Rational Economics ..., s. 93.

33. S. Mullainathan, R.H. Thaler, Behavioral economics, „NBER Working Paper” 2000, 7948, s. 9.

34. S. Benartzi, R. Thaler, Heuristics and Biases in Retirement Savings Behavior, „Journal of Economic Perspectives" 2007, 21(3), 81-104, s. 1.

35. A. Solek, op. cit., s. 25. Ma to również związek z efektem posiadania (endowment effect).

36. M. Czerwonka, B. Gorlewski, Finanse behawioralne. Zachowania inwestorów i rynku, Oficyna Wydawnicza SGH, Warszawa 2012, s. 45. Prawdopodobieństwo dożycia emerytury może być niedoszacowane, a oczekiwanie świadczenia pracy przeszacowane.

37. P. Zielonka, Giełda i psychologia, CeDeWu, Warszawa 2012, s. 83. 
Rysunek 1. Krzywa wartości dla zysków i strat wg Kahnemana i Tversky’ego

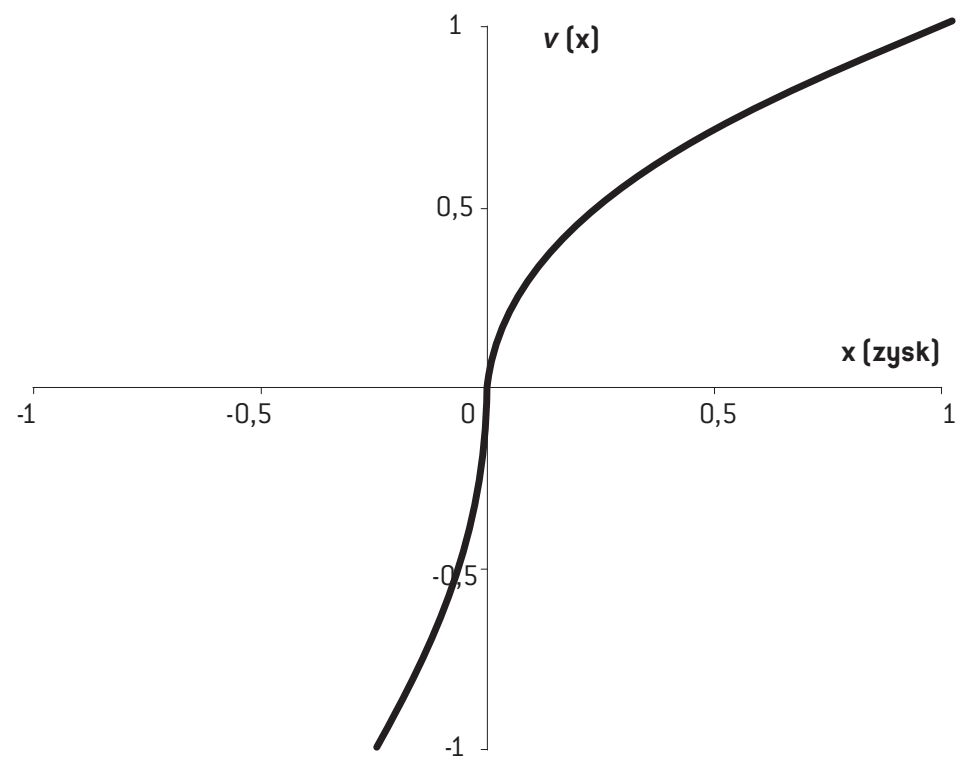

Źródło: P. Zielonka, Efekt dyspozycji a teoria perspektywy, „Decyzje” 2005, nr 3, s. 59.

Rysunek 2. Funkcja wag decyzyjnych

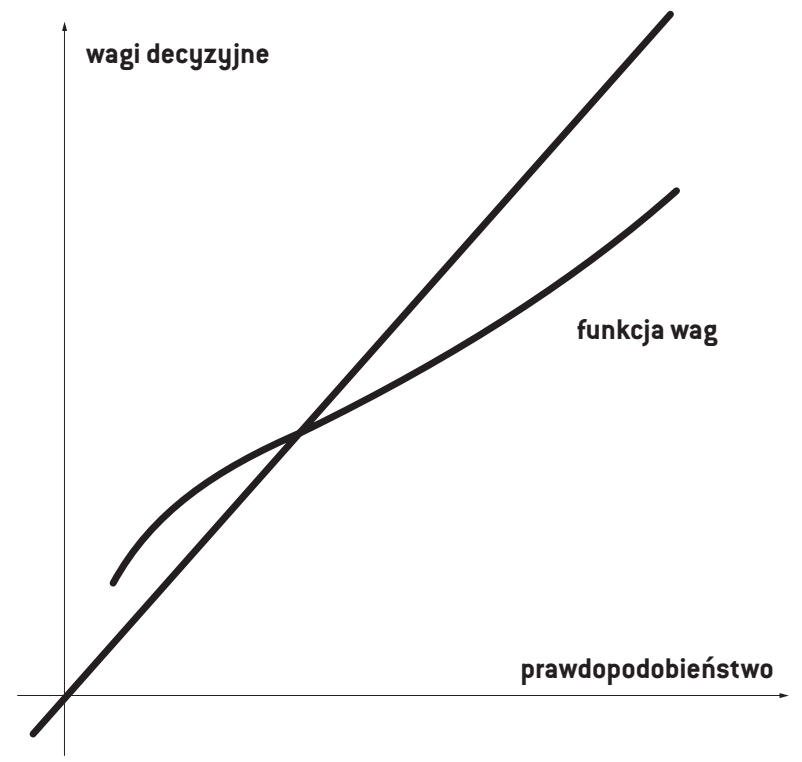

Źródło: P. Zielonka, Efekt dyspozycji a teoria perspektywy, „Decyzje” 2005, nr 3, s. 59.

a nie oszacowania prawdopodobieństwa jako takiego. Zdaniem Adriana Solka w teorii perspektywy użyteczność nie zależy od rzeczywistego prawdopodobieństwa, ale właśnie od wagi decyzyjnej, czyli subiektywnego odwzorowania wartości. Rysunek 2. przedstawia funkcję wag decyzyjnych. 
Wnioski przedstawione powyżej maja znaczenie dla podejmowania decyzji oszczędnościowych, albowiem oszczędzanie w kapitałowych programach emerytalnych o formule zdefiniowanej składki niemal nierozerwalnie związane jest z koniecznościa podejmowania ryzyka związanego z inwestowaniem składek ${ }^{38}$. Niechęć do podejmowania ryzyka może powodować niechęć do rozpoczęcia oszczędzania. W świetle teorii perspektywy nietrudno wytłumaczyć preferencję do oszczędzania na lokatach bankowych zamiast w ryzykownych funduszach inwestycyjnych. Wielkość potencjalnych zysków jest postrzegana znacznie niżej od rozmiaru potencjalnej straty.

\subsection{Samokontrola}

David Laibson i jego współautorzy ${ }^{39}$ zaznaczają, że ludzie muszą sprostać dwóm wyzwaniom: podejmowania dobrych decyzji a następnie - ich przestrzegania. Po pierwsze, zawyżona jest ocena wyrafinowania podejmowanych decyzji. Po drugie, istnieje założenie, że intencje i czyny są równoznaczne. Wielu ludzi przypisuje wagę procesowi samokontroli. Jest ona pożądana i wielu ludziom jej brakuje. Ludzie planują mądrze inwestować, a następnie odkładają wykonanie tego planu. ${ }^{40}$

Homo oeconomicus po rozwiązaniu problemu decyzyjnego w celu podjęcia optymalnego wyboru wypełnia swoje postanowienia bez przeszkód. Natomiast ludzie niekiedy nie dają rady tego dokonać ze względu na ograniczenia silnej woli. Brak pełnej samokontroli jest istotny z punktu widzenia planowania emerytalnego z wielu przyczyn. Brunhart wymienia niektóre z nich ${ }^{41}$ :

- Samokontrola jest wytłumaczeniem, dlaczego istnieje różnica pomiędzy tym, co ludzie uważają, że powinni robić, a tym, co tak naprawdę robią.

- Brak samokontroli jest widoczny w rozbieżności między tymi zmianami, które deklarują, a tymi, które wdrażają.

- Samokontrola jest tym trudniejsza, im niższy poziom dochodów. Oszczędzanie jest luksusem dla biednych.

Rozwój teorii poznawczych w psychologii przyczynił się do rozwoju teorii dualistycznych i metafory umysłu jako systemu przetwarzania informacjii ${ }^{42}$. Pierwszą systematyczna próbę formalnego przedstawienia tej koncepcji w ekonomii podjęli Richard Thaler i Hersh Shefrin ${ }^{43}$. Autorzy wprowadzili samokontrolę do formalnego modelu decyzji międzyokresowych, proponując modelowo człowieka jako organizację z „planującym” i wieloma „wykonawcami”. Niespójność preferencji spowodowana jest niecierpliwością i samolubnością „wykonawców”. Najważniejszym zastosowaniem tego

38. Istnieja produkty oszczędnościowe o charakterze lokat bankowych, aczkolwiek niska stopa procentowa oznacza iż nie są one najodpowiedniejszym (choć prawdopodobnie są najbezpieczniejszym) sposobem oszczędzania długoterminowego.

39. D.I. Laibson, A. Repetto, J. Tobacman, R.E. Hall, W.G. Gale, G.A. Akerlof, Self-Control and Saving for Retirement, "Brookings Papers on Economic Activity” 1998, no. 1, s. 92.

40. G.A. Akerlof, Procrastination and Obedience, „The American Economic Review”, vol.ume 81, Issue 2, „Papers and Proceedings of the. Hundred and Third Annual Meeting of the American Economic Association" May 1991, $1-19$, s. 24.

41. N. Brunhart, Individual Financial Planning for Retirement: Empirical Insights from the Affluent Segment in Germany: Contributions to Economics, Psychica-Verlag (Springer), Heidelberg 2008, s. 110-111.

42. E-M. Sent, op. cit., s. 748.

43. R.H. Thaler, H.M. Shefrin, An Economic Theory ..., s. 79. 
modelu jest badanie zachowań oszczędnościowych. Hipotezy stawiane na ich podstawie różnią się znacznie od hipotez dochodu permanentnego i cyklu życia ${ }^{44}$.

W koncepcji Keitha Stanovicha i Richarda Westa ${ }^{45}$ poznanie ludzkie opiera się na dualnym systemie operacyjnym (System 1 i System 2). W tej koncepcji w danym momencie można zastosować „automatycznego pilota”, czyli heurystyczny System 1, który używany jest codziennie do prostszych zadań, lub w pełni racjonalnego (ale raczej leniwego) „kontrolera” w Systemie 2, którego można użyć do trudniejszych zadań i którego aktywacja wymaga skupienia i uwagi. Ludzie zachowują się tak, jak gdyby posiadali dwa zestawy wzajemnie niespójnych preferencji. Myślenie i motywacja, a w konsekwencji ludzkie zachowanie, są wynikiem nierozerwalnej hybrydy tych dwóch systemów. To wymaga wysiłku. System 1 może być zaprezentowany jako racjonalny w sensie neoklasycznym, System 2 ma skłonność do impulsywności. Warto zauważyć, że propozycja ta poddawana jest krytyce zarówno przez ekonomistów, jak i psychologów ${ }^{46}$.

Sama wiedza na temat zabezpieczenia emerytalnego, a nawet deklarowane chęci oszczędzania nie są wystarczające. Niezbędne są odpowiednie sposoby zobowiązania (a nawet przymusu), które przełożą świadomość i konieczność działania na konkretne działanie ${ }^{47}$.

\subsection{Księgowanie mentalne [umysłowe]}

Ważnym założeniem w teorii neoklasycznej jest wymienialność (fungibility) różnych form pieniądza. System kont mentalnych nie zgadza się z zasadą pełnej substytucyjności ${ }^{48}$. Prostą metodą wskazania, jak ludzie zachowują się odnośnie różnych form dochodu i majątku jest założenie, że ludzie stosują system kont mentalnych (umysłowych). Księgowanie mentalne ${ }^{49}$ lub system kont mentalnych ${ }^{50}$, zakłada, że ludzie różnie postrzegają dochód bieżący (current income I/C), oszczędności bieżące (current assets A) i dochód przyszły (future income F). Krańcowa skłonność do konsumpcji jest najwyższa dla konta I/C, pośrednia dla A i najmniejsza dla konta $\mathrm{F}^{51}$. Księgowanie mentalne ma związek z efektem "oprawy” (framing effect) ${ }^{52}$. Thaler wymienia następujące zasady, których przestrzegaja gospodarstwa domowe ${ }^{53}$.

44. Ibidem, s. 88.

45. Szczegółowy przegląd literatury dotyczącej tej koncepcji można znaleźć w: J. Evans, In two minds: Dual-process accounts of reasoning, „Trends in Cognitive Sciences” 2003, ? (10), October.

46. K. Fiedler, M. von Sydow, op. cit., s. 146, 153-154.

47. N. Brunhart, op. cit., s. 111.

48. P. Bańbuła, Oszczędności i wybór międzyokresowy - podejście behawioralne, „Materiały i Studia. Narodowy Bank Polski" 2006, z. 208, s. 34-36.

49. R.H. Thaler, Mental Accounting and Consumer Choice, „Marketing Science”, 1985, 4(3), s. 199-214.

50. R.H. Thaler, Mental Accounting Matters, „Journal of Behavioral Decision Making” 1999, 12 (3), s. 183-206.

51. R.H. Thaler, Saving, Fungibility and Mental Accounts, „Journal of Economic Perspectives” 1990, vol. 4 No 1 Winter, s. 194.

52. D. Kahneman, A. Tversky, Rational Choice and the Framing of Decisions. „The Journal of Business” 1986, 59, s. 251-278. Dobre tłumaczenie tego terminu zaproponował M. Szczepański: „formatowanie” lub „kadrowanie", zob.: M. Szczepański, op. cit., s. 31.

53. R.H. Thaler, Saving ..., s. 195. 
Tabela 2. Zestawienie kont mentalnych

\begin{tabular}{|l|l|l|}
\hline \multicolumn{1}{|c|}{ Konto } & \multicolumn{1}{|c|}{ Zasada } & \multicolumn{1}{c|}{ Implikacja } \\
\hline Bieżące (Current) & Nie żyj ponad stan. & $\begin{array}{l}\text { Konsumpcja przesadnie podąża } \\
\text { za dochodem. }\end{array}$ \\
\hline $\begin{array}{l}\text { Oszczędności } \\
\text { (Assets) }\end{array}$ & $\begin{array}{l}\text { Trzymaj „zaskórniaki” i używaj tylko } \\
\text { w razie konieczności. }\end{array}$ & To konto jest niewielkie. \\
\hline Przyszłe (Future) & $\begin{array}{l}\text { Oszczędzaj na emeryturę tak, aby jak } \\
\text { najmniej wymagać samokontroli. }\end{array}$ & $\begin{array}{l}\text { Większość oszczędności emerytalnych nie } \\
\text { jest dobrowolna. Ludzie nie traktują zasobów } \\
\text { emerytalnych tak samo jak innych. }\end{array}$ \\
\hline
\end{tabular}

Źródło: opracowanie własne na podstawie: R.H. Thaler, Saving, Fungibility and Mental Accounts, „Journal of Economic Perspectives" 1990, vol. 4 No 1 Winter, s. 195.

Zdaniem Thalera ${ }^{55}$ księgowanie umysłowe (mentalne) jest zbiorem działań poznawczych wykorzystywanych przez gospodarstwa domowe do organizowania, ewaluacji i kontroli działań finansowych. Ludzie maja po prostu pewne utarte przyzwyczajenia ${ }^{56}$. Krańcowa skłonność do konsumpcji premii uznaniowych i nagród jest niższa od konsumpcji regularnego dochodu. Racjonalny człowiek spodziewa się premii, więc powinien traktować ja jako zwykły dochód, a nie coś specjalnego. Jednakże tak nie jest. Dlatego premie mogą stanowić doskonały sposób na zasilenie konta emerytalnego, o ile sprzyjaja ku temu pozostałe warunki systemowe.

\subsection{Wybory międzyokresowe}

Wybory międzyokresowe to decyzje dotyczące wyborów kosztów i korzyści występujących w różnym czasie. Wybory te są istotne i powszechne ${ }^{5 ?}$.

Zgodnie ze standardową teorią ekonomii wszyscy ludzie podejmujący decyzje dyskontują wykładniczo ${ }^{58}$. Ponadto, decyzje powinny być spójne w czasie. Ekonomicznie racjonalne jest założenie wykładniczego obniżenia wartości o taki sam procent w kolejnych jednostkach czasu. Ludzie powinni podejmować decyzje międzyokresowe w taki sposób, aby ich korzyść równa była zdyskontowanemu zyskowi z oprocentowania.

Sprzeczne ze standardową teorią dyskontowanie niewykładnicze oznacza, że przy założeniu dodatniej stopy zwrotu w długim okresie postrzegana wartość dochodu przyszłego jest znacznie mniejsza niż w przypadku obliczenia wartości przy użyciu dyskontowania wykładniczego, a tym samym istotnie mniej atrakcyjna ${ }^{59}$. Subiektywna funkcja dyskonta ma zwykle kształt hiperboli, co oznacza, że oszacowana wartość wypłaty jest odwrotnie proporcjonalna do czasu oczekiwania na nią. Funkcje hiperboliczne implikują stopy dyskonta, które zmniejszają się wraz z oddaleniem

54. Ibidem, s. 199.

55. R.H. Thaler, Mental Accounting Matters ..., s. 184.

56. H.M. Shefrin, R.H. Thaler, The Behavioral Life-Cycle ..., s. 114.

57. S. Frederick, G. Loewenstein, T. O'Donoghue, Time Discounting and Time Preference: A Critical Review, [w:] Advances in Behavioural Economics, [red.] C.F. Camerer, G. Loewenstein, M. Rabin, Russell Sage Foundation NY, University Press Princeton and Oxford, Princetown2004, s. 162-222.

58. N. Brunhart, op. cit. s. 94.

59. Dlatego zastosowanie kalkulatorów emerytalnych i prezentacji informacji z wykorzystaniem określonych prognoz wydaje się więc mieć potencjalny wpływ na podejmowane wybory. W ten sposób pomaga się ludziom dokonać skomplikowanych obliczeń. 
wydarzenia w czasie. Wydarzenia bliżej teraźniejszości są dyskontowane przy użyciu wyższej stopy dyskonta niż te z przyszłości ${ }^{60}$.

Rysunek 3. Wykresy funkcji dyskonta: wykładniczej, hiperbolicznej i quasi-hiperbolicznej

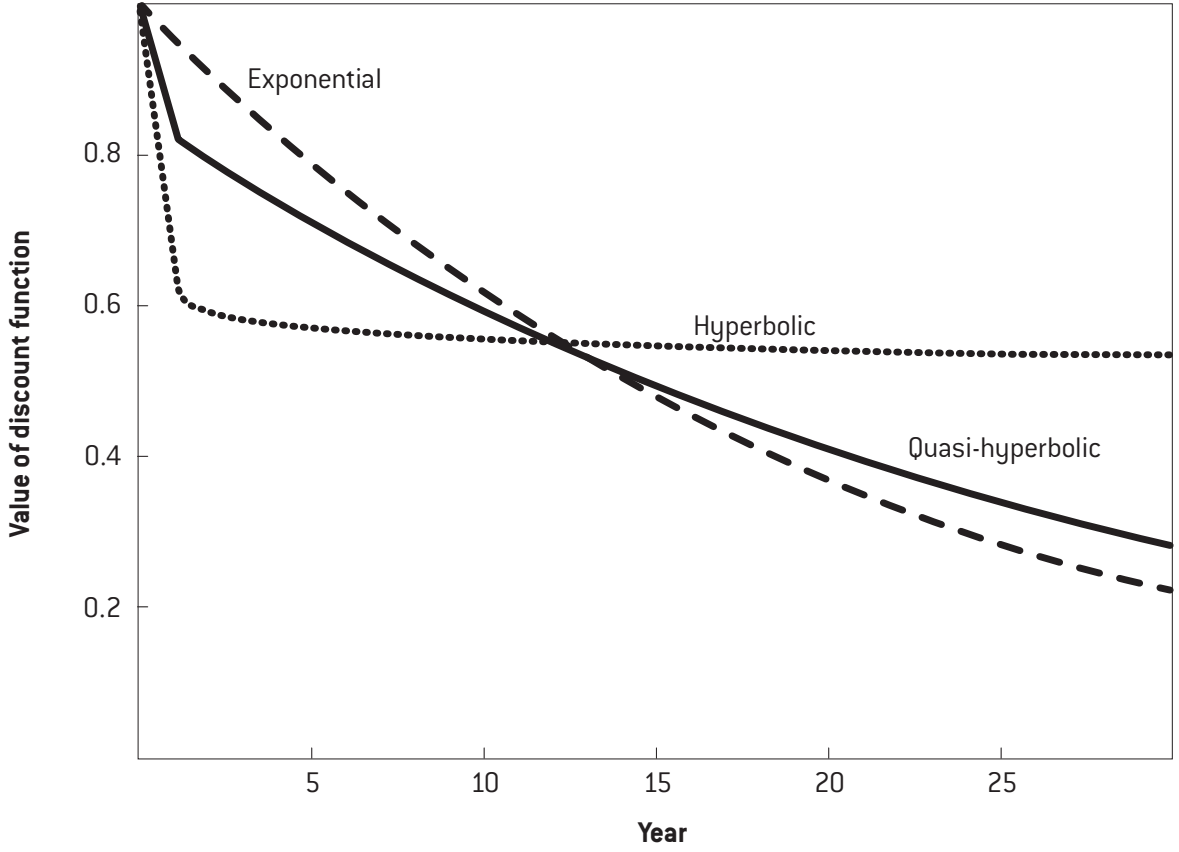

Źródło: D.I. Laibson, A. Repetto, J. Tobacman, R.E. Hall, W.G. Gale, G.A. Akerlof, Self-Control and Saving for Retirement, „Brookings Papers on Economic Activity” 1998, no. 1, s. 9 ?.

W celu ułatwienia obliczeń często używa się wykresu quasi-hiperbolicznego. Quasi-hiperboliczna funkcja jest wygodnym uproszczeniem, które pozwala zachować hiperboliczność, a jednocześnie ułatwia modelowanie i dalsze analizy.

Prowadzi to do wniosku, że dyskontowanie niewykładnicze powoduje istotny problem samoregulacji zachowania związanego z zabezpieczeniem emerytalnym. Modele niewykładnicze wskazują na niespójność preferencji w czasie ${ }^{61}$. Ludzie przypisują tym większą wagę dobrobytowi krótkoterminowemu, im jest on bliżej ${ }^{62}$. Strotz ${ }^{63}$ jako pierwszy rozpatrywał alternatywne modele dyskontowania niewykładniczego. Zauważył, że w każdym wypadku niewykładniczego dyskontowania człowiek oznacza się niespójnością preferencji w czasie.

60. D.I. Laibson, A. Repetto, J. Tobacman, R.E. Hall, W.G. Gale, G.A. Akerlof, op. cit., s. 99.

61. Laibson, D., et al. Self-Control ... op. cit. str. 95

62. T. O'Donoghue, M. Rabin, Procrastination in Preparing for Retirement, [w:] Behavioral Dimensions of Retirement Economics, ed H. Aaron. Washington D.C.: The Brookings Institute, 1999 str. 6

63. S. Frederick, G. Loewenstein, T. O'Donoghue, op. cit., s. 179. 
W związku z tym, człowiek stosować może dwie strategie radzenia sobie z ową niespójnością. Są to strategia zobowiązania (precommitment), przejawiająca się przystępowaniem do rozmaitych inicjatyw oszczędnościowych, oraz strategia ciagłego planowania.

W przypadku strategii ciagłego planowania osoba o niespójnych preferencjach może być:

- „naiwna” (naive), czyli wierząca, że jej przyszłe preferencje będą takie same jak obecne lub

- „wyrafinowana” (sophisticated) - świadoma, że zmienią się jej preferencje i poprawnie przewidująca zmianę w czasie $^{64}$.

Jednakże zgodnie z błędem „prognozy” (projection bias) ludzie być może wiedzą, że nastapią zmiany, ale systematycznie zaniżaja ocenę rozmiaru tych zmian ${ }^{65}$.

Shefrin i Thaler ${ }^{66}$ omawiaja rozbieżność pomiędzy zamiarami a czynami. Istnieje pewna grupa ludzi, którzy prawdopodobnie zdają sobie sprawę, że powinni więcej oszczędzać na emeryturę, ponadto deklarują taki zamiar, jednakże albo odkładaja decyzję „na potem” (prokrastynacja), albo nie wiedzą, co mają zrobić i nie podejmuja żadnej decyzji, uznając, że „jakoś to będzie” (inercja, myopia]. Podejście takie dotyczy zwłaszcza zadań nieprzyjemnych, co w rezultacie oznacza odroczenie zmiany?

Zdaniem Brunhart dyskontowanie hiperboliczne z punktu widzenia planowania emerytalnego jest ważne z dwóch względów ${ }^{68}$ :

- Po pierwsze, ludzie przeszacowuja wartość konsumpcji „dzisiaj”, tym samym poziom konsumpcji jest zbyt wysoki.

- Po drugie, perspektywa długoterminowa nie wpływa znacząco na zachowanie ludzi, albowiem wartość odroczonej konsumpcji jest postrzegana jako niższa od dyskontowania wykładniczego. Preferencja teraźniejszości w połączeniu z niedoszacowaniem wartości odroczonej konsumpcji przekłada się na krótkowzroczność i obniżoną motywację oszczędzania. W efekcie ludzie nie doceniają wartości oszczędzania długoterminowego w celach emerytalnych.

\section{Postulat dostosowania wybranych rozwiązań behawioralnych w Polsce}

Gdyby ludzie byli w pełni racjonalni, to znaczy postępowali zgodnie z teorią maksymalizacji i optymalizacji oraz myśleli zgodnie z regułami wnioskowania statystycznego, wówczas żadne zachęty - czy to podatkowe, czy informacyjne - nie byłyby potrzebne. Ludzie bowiem sami dobrze wiedzieliby, ile potrzebują i w jaki sposób zaoszczędzić. Nie mieliby też żadnych trudności w realizacji swoich zamierzeń.

Jeżeli rozluźnione jest założenie pełnej racjonalności, to uproszczenie sposobu, w jaki podejmowane są decyzje, prawdopodobnie ma wpływ na ich jakość. Na podstawie mechanizmów przedstawionych w części zasadniczej artykułu zostały opracowane metody oddziaływania i stymulacji
64. Ibidem, s. 181.
65. Ibidem, s. 18 ?.
66. H.M. Shefrin, R.H. Thaler, An Economic Theory...
67. N. Brunhart, op. cit. s. 107.
68. Ibidem, s. 95. 
dozabezpieczenia emerytalnego ${ }^{69}$. Na szczególną uwagę w tym miejscu zasługuje wyszczególnienie kategorii i technik architektury wyboru (metod behawioralnych).

Tabela 3. Kategorie i techniki architektury wyboru

\begin{tabular}{|c|c|c|}
\hline Kategoria & Technika & Przykłady \\
\hline \multirow{3}{*}{$\begin{array}{l}\text { A. Informowanie } \\
\text { decyzji }\end{array}$} & A1 Tłumaczenie informacji & $\begin{array}{l}\text { upraszczanie, kadrowanie / (oprawianie) ale też } \\
\text { używanie prostego języka }\end{array}$ \\
\hline & A2 Uwidacznianie informacji & $\begin{array}{l}\text { dawanie przykładów (np. kampanie } \\
\text { informacyjne, dostarczanie czytelnych i jasnych } \\
\text { wyciagów z kont oszczędnościowych, kalkulatory } \\
\text { i prognozy emerytalne) }\end{array}$ \\
\hline & $\begin{array}{l}\text { A3 Wskazanie społecznych punktów } \\
\text { odniesienia }\end{array}$ & $\begin{array}{l}\text { odniesienie do norm deskryptywnych, opinii } \\
\text { liderów / autorytetów (też np. ukazanie koszyka } \\
\text { dostępnych świadczeń przy danym poziomie } \\
\text { emerytury) }\end{array}$ \\
\hline \multirow{4}{*}{$\begin{array}{l}\text { B. Struktura } \\
\text { decyzji }\end{array}$} & B1 Zmiana opcji domyślnej & $\begin{array}{l}\text { ustawienie opcji w przypadku braku aktywnego } \\
\text { podjęcia decyzji, zastosowanie konieczności } \\
\text { podjęcia decyzji (np. zapis automatyczny lub } \\
\text { przyspieszony) }\end{array}$ \\
\hline & $\begin{array}{l}\text { B2 Zmiana poziomu wysiłku } \\
\text { wymaganego do podjęcia decyzji }\end{array}$ & $\begin{array}{l}\text { podniesienie albo obniżenie fizycznego lub } \\
\text { finansowego wysiłku (np. automatyczna } \\
\text { eskalacja składek, upraszczanie formalności) }\end{array}$ \\
\hline & B3 Zmiana zasięgu lub zestawu opcji & $\begin{array}{l}\text { zmiana kategorii, zmiana pogrupowania opcji } \\
\text { (np. ustalenie strategii inwestycyjnej) }\end{array}$ \\
\hline & B4 Zmiana konsekwencji opcji & $\begin{array}{l}\text { połączenie decyzji z zyskiem lub kosztem, } \\
\text { zmiana konsekwencji społecznych } \\
\text { podejmowanych decyzji (np. premia na start) }\end{array}$ \\
\hline \multirow[b]{2}{*}{$\begin{array}{l}\text { C. Wspomaganie } \\
\text { decyzji }\end{array}$} & C1 Dostarczenie przypomnień & komunikacja \\
\hline & $\begin{array}{l}\text { C2 Ułatwienie wypełnienia podjętych } \\
\text { zobowiazzań }\end{array}$ & $\begin{array}{l}\text { wsparcie samo-zobowiązań lub publicznych } \\
\text { zobowiązań (np. umożliwienie wpłat } \\
\text { bezpośrednio z listy płac) }\end{array}$ \\
\hline
\end{tabular}

Źródło: opracowanie własne na podstawie: R. Münschner, M. Vetter, T. Scheuerle, A Review and Taxonomy of Choice Architecture Techniques, „Journal of Behavioral Decision Making” 2015, D0I: 10.1002/bdm.1897, s. 1.

Architektura wyboru powinna pozwalać na uproszczenie procesu decyzyjnego. Dostęp do informacji powinien być prosty, a sama informacja przejrzysta i łatwa do zrozumienia (np. wyniki funduszy, prognozy emerytalne, kalkulatory świadczeń). Mechanizmy wspomagające utrzymanie postanowień ustalone ( $\mathrm{np}$. zlecenie stałe lub polecenie zapłaty zamiast dowolnych wpłat może po prostu „przypomnieć” o swoim własnym postanowieniu). Wtedy podejmowanie decyzji dotyczących dodatkowego zabezpieczenia emerytalnego będzie łatwiejsze, a realizacja celu bardziej prawdopodobna.

Architektura wyboru odnosi się do idei, że zmiany w otoczeniu decyzyjnym moga wpłynąc na decyzje podejmowane przez jednostki, przy zachowaniu wolności wyboru. Podejście to zmienia

69. Więcej na temat architektury wyboru zob. m.in.: S. Pieńkowska-Kamieniecka, Automatyczne plany emerytalne w systemie dodatkowego zabezpieczenia emerytalnego - przesłanki tworzenia i funkcjonowania, [w:] Doubezpieczenie społeczne - idea i kontynuacja, [red.] M. Kawiński, Szkoła Główna Handlowa, Warszawa 2015; W. Sieczkowski, Decyzje oszczędnościowe ..., op. cit. 
zachowanie bez zabraniania innych opcji, jak również bez istotnych zmian pozostałych zachęt ekonomicznych ${ }^{20}$. Nie ulega jednak wạtpliwości, że w analizie skuteczności i efektywności działań mających na celu zachęcanie do zwiększania dozabezpieczenia należy, obok metod behawioralnych, brać pod uwagę czynniki klasyczne, od fiskalnych (ulgi podatkowe i dopłaty), poprzez te dotyczące poziomu wiedzy uczestników, aż po te dotyczące sposobu przekazywania informacji emerytalnej i tzw. marketingu społecznego ${ }^{71}$. Należy podkreślić, że na wybory wpływa szereg czynników wymienionych powyżej, a ich wzajemne relacje są nierozerwalne (chociażby z powodów metodologicznych).

Ponadto należy zauważyć, że choć procesy poznawcze są w głównej mierze takie same na całym świecie, to decyzje emerytalne nie sa podejmowane „w próżni”. Punktem odniesienia

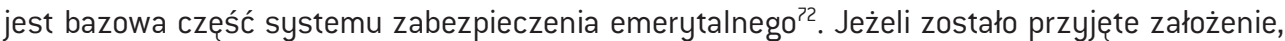
że wpływ na jakość decyzji ma architektura wyboru, to tym bardziej system bazowy musi mieć istotny wpływ na podejmowane decyzje, jako jeden z podstawowych determinantów poziomu zabezpieczenia emerytalnego. Problem optymalizacji oszczędności jednostki musi uwzględniać wszystkie źródła dochodu, a także oczekiwania wobec podmiotów ekonomicznych dostępnych na rynku (państwo, pracodawca i gospodarstwa domowe) ${ }^{73}$.

Reforma systemu emerytalnego w Wielkiej Brytanii nie tylko wprowadziła zapis automatyczny, ale również uprościła system bazowy ${ }^{74}$. Nowozelandzki system bazowy New Zealand Supperannuation (NZS) jest powszechnie uznawany za jeden z najprostszych w OECD. Nie ma testów dochodowych, historii składek, jedynie prosty wymóg rezydencji. Struktura Kiwi Savera jest prosta, podobnie jak NZS ${ }^{75}$. To w tych państwach skutecznie wprowadzono automatyczny zapis do kapitałowych programów emerytalnych. Z kolei wprowadzenie automatycznego zapisu we Włoszech nie zaowocowało tak pozytywnymi rezultatami6. Dlatego należy postulować dostosowanie znanych rozwiązań do systemu zabezpieczenia emerytalnego w Polsce ${ }^{\text {? }}$.

70. Autorzy zauważają wprost, że żadne formy obowiazzkowości lub klasyczne zachęty ekonomiczne nie stanowia architektury wyboru; zob. R.H. Thaler, C. Sunstein, The Nudge, Yale University Press, New Haven 2008, s. 6; R. Münschner, M. Vetter, T. Scheuerle, op. cit., s. 1.

71. T. Crossley, C. Emmerson, C. Leicester, Raising Household Saving, Institute For Fiscal Studies, London February 2012.

72. T. Szumlicz, Ekwiwalentność funduszowa i kompensacyjna w systemie zabezpieczenia społecznego, „Wiadomości Ubezpieczeniowe" 2017, nr 2, s. 19.

73. W porzadku korporatystycznym i uniwersalistycznym nie ma wymogu tak istotnego zaangażowania obywateli w dobrowolne programy emerytalne. Sa one natomiast istotnym elementem w porzadku liberalnym, zob. F. Chybalski, System emerytalny a wybrane decyzje emerytalne - analiza ilościowa dla krajów europejskich, „Polityka Społeczna” 2017, nr 4, s. 8.

74. W. Sieczkowski, Reforma systemu emerytalnego w Wielkiej Brytanii, „Wiadomości Ubezpieczeniowe” 2014, $\mathrm{nr} 2$.

75. G. Rashbrooke, Simple, effective and (relatively) inexpensive: New Zealand retirement provision in the international context, „Social Policy Journal of New Zealand” 2009, nr 36, s. 98

76. W. Sieczkowski, Decyzje ..., s. 92-93.

77. W Polsce zastosowano metodę behawioralną w trakcie reformy OFE (PTE) w 2014 roku. Opcja domyślną było przeniesienie do FUS (ZUS). Od tamtej pory opcją domyślną jest wpłacanie składek na subkonto w ZUS. Por. W. Sieczkowski, „Automatic Dis-Enrolment”. Impact of Choice Architecture on Retirement Savings Decisions: Some evidence from Poland, „Wiadomości Ubezpieczeniowe” 2014, nr 4. 


\section{Zakończenie}

Metody behawioralne powstawały w wyniku obserwowanych i badanych odstępstw od neoklasycznych założeń racjonalności. Miały na celu usprawnienie procesu decyzyjnego i poprawę jakości dokonywanych wyborów. W nawiązaniu do znaczącego wzrostu zainteresowania decyzjami emerytalnymi w zakresie dodatkowego oszczędzania emerytalnego ${ }^{78}$, zwłaszcza wykorzystujacymi elementy behawioralne, wydaje się uzasadnionym, aby przy wprowadzaniu rozwiązań behawioralnych w polskim systemie emerytalnym zaproponować powrót do źródła (back to basics) i przygotować rozwiązania specyficzne dla polskiego systemu emerytalnego ${ }^{79}$.

W tym celu dogłębnej analizie poddano pojęcie racjonalności używane w ekonomii behawioralnej, następnie przedstawiono propozycję rozdzielenia pojęć związanych z ekonomią behawioralną na część eksplanacyjna, preskryptywną i zastosowania. Część główna poświęcona została pięciu głównym mechanizmom:

- heurystykom poznawczym,

- teorii perspektywy,

- samokontroli,

- księgowaniu mentalnemu,

- wyborom międzyokresowym.

Na zakończenie syntetycznie przedstawiono metody behawioralne powstałe w wyniku identyfikacji zaobserwowanych mechanizmów oraz przedstawiono postulat dostosowania rozwiązań do specyfiki systemu emerytalnego w Polsce.

\section{Wykaz źródeł}

Advances in Behavioral Economics, Camerer C.F., Loewenstein G., Rabin M. [red.], Russell Sage Foundation NY, University Press Princeton and Oxford, Princeton 2004.

Akerlof G.A., Procrastination and Obedience, „The American Economic Review” May 1991, vol.ume 81, Issue 2, Papers and Proceedings of the Hundred and Third Annual Meeting of the American Economic Association.

Bańbuła P., Oszczędności i wybór międzyokresowy - podejście behawioralne, „Materiały i Studia. Narodowy Bank Polski” 2006, zeszyt 208.

Benartzi S., Thaler R., Heuristics and Biases in Retirement Savings Behavior, „Journal of Economic Perspectives" 200?, 21(3).

Brunhart N., Individual Financial Planning for Retirement: Empirical Insights from the Affluent Segment in Germany: Contributions to Economics, Psychica-Verlag (Springer), Heidelberg 2008. Chybalski F., System emerytalny a wybrane decyzje emerytalne. Analiza ilościowa dla krajów europejskich, „Polityka Społeczna” 2017, nr 4.

Crossley T., Emmerson C., Leicester C., Raising Household Saving, Institute For Fiscal Studies, London 2012.

78. S. Pieńkowska-Kamieniecka, Wybrane aspekty..., s. 20.

79. Autor postuluje, aby wykorzystać doświadczenia z wykorzystania rozwiązań behawioralnych, ale z naciskiem na ich adaptację do specyficznych warunków polskiego systemu emerytalnego. 
Czerwonka M., Gorlewski B., Finanse behawioralne. Zachowania inwestorów i rynku, Oficyna Wydawnicza SGH, Warszawa 2012.

Evans J., In two minds: Dual-process accounts of reasoning, "Trends in Cognitive Sciences” October 2003, ? (10).

Fiedler K., von Sydow M., Heuristics and Biases: Beyond Tversky and Kahneman's (1974) Judgment under Uncertainty, [w:] Eysenck M.W., Groome D., Cognitive Psychology: Revisiting the Classical Studies, Sage, Los Angeles-London 2015.

Frederick, S., G. Loewenstein, T. O'Donoghue, Time Discounting and Time Preference: A Critical Review, [w: ] Camerer, C.F., G. Loewenstein, M. Rabin Advances in Behavioural Economics, Russell Sage Foundation NY, University Press Princeton and Oxford, Princetown 2004, s. 162-222

Godłów-Legiędź J., Ekonomia behawioralna: Od koncepcji racjonalności do wizji ustroju ekonomicznego, „Ekonomia” 2013, 4(25).

Goldstein D.G., Gigerenzer G., Models of ecological rationality: The recognition heuristic, „Psychological Review" 2002, vol. 109, no. 1.

Góra M., System emerytalny, Wydawnictwo Ekonomiczne, Warszawa 2003.

Hayek and Behavioral Economics, Frantz R., Leeson R. [red.], Palgrave-Macmillan, London 2013. Kahneman D., Tversky A., Judgment under uncertainty: Heuristics and biases, „Science” 1974, 185.

Kahneman D., Tversky A., Prospect Theory: An Analysis of Decision under Risk, „Econometrica” 1979, 47 [2], March.

Kahneman D., Tversky A., Rational Choice and the Framing of Decisions, „The Journal of Business” 1986, 59.

Laibson D.I., Repetto A., Tobacman J., Hall R.E., Gale W.G., Akerlof G.A., Self-Control and Saving for Retirement, „Brookings Papers on Economic Activity” 1998, no. 1.

Mitchell S., Utkus S., Pension Design and Structure: New Lessons from Behavioral Finance, Palgrave, New York 2004.

Mullainathan S., Thaler R.H., Behavioral economics, „NBER Working Paper” 2000, 7948.

Münschner R., Vetter M., Scheuerle T., A Review and Taxonomy of Choice Architecture Techniques, „Journal of Behavioral Decision Making” 2015, D0l: 10.1002/bdm.189?.

O'Donoghue T., Rabin M., Procrastination in Preparing for Retirement, [w:] Behavioral Dimensions of Retirement Economics, Aaron H. [red.], The Brookings Institute, Washington D.C. 1998.

Pieńkowska-Kamieniecka S., Wybrane aspekty dodatkowego oszczędzania emerytalnego - perspektywa behawioralna, „Studia Oeconomica Posnaniensia” 2017, tom 10.

Pieńkowska-Kamieniecka S., Automatyczne plany emerytalne w systemie dodatkowego zabezpieczenia emerytalnego - przesłanki tworzenia i funkcjonowania, [w:] Doubezpieczenie społeczne - idea i kontynuacja, Kawiński M. [red.], Szkoła Główna Handlowa, Warszawa 2015.

Rashbrooke G., Simple, effective and (relatively) inexpensive: New Zealand retirement provision in the international context, „Social Policy Journal of New Zealand” 2009, nr 36.

Sent E.-M., Behavioral Economics: How Psychology Made Its (Limited) Way Back Into Economics, „History of Political Economy” 2004, 36, issue 4.

Shefrin, H.M., Thaler R.H., The Behavioral Life-Cycle Hypothesis, [w:] Thaler R.H., Quasi Rational Economics, Russell Sage Foundation, New York 2000.

Shefrin H.M., Thaler R.H., An Economic Theory of Self-Control, „Journal of Political Economy” 1981, vol. 89[2] April. 
Sieczkowski W., Reforma systemu emerytalnego w Wielkiej Brytanii, „Wiadomości Ubezpieczeniowe” 2014, $\mathrm{nr} 2$.

Sieczkowski W., „Automatic Dis-Enrolment”. Impact of Choice Architecture on Retirement Savings Decisions: Some evidence from Poland, „Wiadomości Ubezpieczeniowe” 2014, nr 4.

Sieczkowski W., Decyzje oszczędnościowe w systemie zabezpieczenia emerytalnego w Doubezpieczenie społeczne - idea i kontynuacja, Kawiński M. [red.], Szkoła Główna Handlowa, Warszawa 2015.

Solek A., Ekonomia behawioralna a ekonomia neoklasyczna, „Zeszyty Naukowe - Polskie Towarzystwo Ekonomiczne" 2010, nr 8.

Szumlicz T., Ubezpieczenie społeczne. Teoria dla praktyki, Oficyna Wydawnicza Branta, BydgoszczWarszawa 2005.

Szumlicz T., Ekwiwalentność funduszowa i kompensacyjna w systemie zabezpieczenia społecznego, „Wiadomości Ubezpieczeniowe” 2017, nr 2.

Szczepański M., Wykorzystanie dorobku ekonomii behawioralnej w reformowaniu systemów emerytalnych, „Polityka Społeczna” 2017, nr 8.

Thaler R.H., Quasi Rational Economics, Russell Sage Foundation, New York 2000.

Thaler R.H., Saving, Fungibility and Mental Accounts, „Journal of Economic Perspectives” 1990, vol. 4, no. 1 Winter.

Thaler R.H., Mental Accounting and Consumer Choice, „Marketing Science” 1985, 4[3].

Thaler R.H., Mental Accounting Matters, „Journal of Behavioral Decision Making” 1999, 12 (3).

Thaler R.H., Sunstein C., The Nudge, Yale University Press, New Haven 2008.

Thaler R.H., Shefrin H.M., An Economic Theory of Self-Control, „Journal of Political Economy” 1981, 89, 2 April.

Tomer J.F., What is behavioral economics?, „The Journal of Socio-Economics” 2007, 36.

Zielonka P., Efekt dyspozycji a teoria perspektywy, „Decyzje” 2005, nr 3.

Zielonka P., Behawioralne aspekty inwestowania na rynku papierów wartościowych, CeDeWu, Warszawa 2008.

Zielonka P., Giełda i psychologia, CeDeWu, Warszawa 2012.

\section{Behavioural aspects of the additional pension savings decisions [applications for Poland]}

The aim of the article is to present the concept of rationality and limitations of rationality in the field of behavioral economics, as the basis to create behavioral methods aimed at improving the quality of decisions concerning additional pension savings. Based on an in-depth analysis of the literature, it is postulated to adapt selected behavioral solutions to the specific conditions of the retirement system in Poland.

WOJCIECH SIECZKOWSKI - doktorant, Szkoła Główna Handlowa w Warszawie, Katedra Ubezpieczenia Społecznego 